\title{
Financial Autonomy of Local Governments in the Slovak Republic: A Panel Data Investigation ${ }^{1}$
}

\author{
Lenka MALIČKÁ*
}

\begin{abstract}
Autonomy of local governments consists also in the financial autonomy. In the SR, the municipal financial autonomy is importantly influenced by dominant position of shared tax in the municipal tax revenue. When considering only own revenues (own tax and nontax), the financial autonomy of municipalities is low. In this paper the financial autonomy of municipalities in the $S R$ is analyzed in the period 2005 - 2019. At the base of the Gini index, inequalities in financial autonomy are analyzed. Higher inequalities are observed in case of the exclusion of shared tax, what confirms that the shared tax serves as a channel of horizontal fiscal equalization. Employing the panel regression, determinants of financial autonomy are analyzed. The negative relationship is observed in case of the population growth, use of returnable financial resources, financial crisis and also the portion of shared tax on municipal tax revenue, when considering the financial autonomy based on own resources.
\end{abstract}

Keywords: local financial autonomy, fiscal decentralization, local government, local budget, local tax, shared tax, panel data

JEL Classification: H71, H73, H77

DOI: https://doi.org/10.31577/ekoncas.2021.07.01

\section{Introduction}

In Europe, the importance of local governments increased after the adoption of the European Charter of Local Self-Government (1985), which promotes local autonomy and defines it as "the right and the ability of local authorities, within the limits of the law, to regulate and manage a substantial share of public affairs

\footnotetext{
* Lenka MALIČKÁ, Technical University of Košice, Faculty of Economics, Department of Economics Finance, Němcovej 32, 04001 Košice, Slovak Republic; e-mail: lenka.malicka@tuke.sk

${ }^{1}$ This work was supported by the grant APVV-18-0368.
} 
under their own responsibility and in the interests of the local population". Since then, decentralization of the public sector has taken place in many European countries. Administrative decentralization was generally accompanied by fiscal decentralization. Central and East European (CEE) countries, including the Slovak Republic (SR), followed the decentralization trends simultaneously with their transformation to market-oriented economies. Blair (1991) mentions that in European countries the starting-points, from which their systems evolved, were different. Some of them were more centralized and stayed centralized even after reforms of the public sector and public finances.

In the early 90's, the SR became an autonomous republic (after the dissolution of the Czech and Slovak Federative Republic) and saw the establishment of authorities at the central level of government. Although the existence of the municipal level of government during this period was obvious, the economic recession in the years 1995 - 1996 caused the continuance of the centralization, after which the first step towards decentralization was made. The real process of public administration decentralization and fiscal decentralization was launched in the beginning of $21^{\text {st }}$ century. In 2002, the establishment of the regional level of government responded to the trends of regionalization in the European Union (EU). Wide responsibilities were shifted to regional and municipal governments. In 2005, the revenue decentralization was implemented in the SR with the expectation of higher financial autonomy of sub-national governments as one of the fiscal decentralization main goals (Nižňanský, Cibáková and Hamalová, 2014). Beside it, mechanisms of horizontal equalization using a shared tax were adopted to smoothen the existing regional disparities and inequalities in the municipal development ability of the municipal development.

The research was motivated by the unequal economic development in the SR's different areas (regions) and the persistent problem of fragmented residential structure in the SR. Accordingly, the source seeking ability of local governments as well as their financial autonomy are different. The aim of the paper is to examine the financial autonomy of municipalities in the SR at the base of various financial autonomy indicators reflecting the different employment of shared tax and own resources (own tax and nontax revenue). The paper also searches for inequalities in local financial autonomy using the Gini index. Finally, the financial autonomy determinants are analyzed using the panel regression. The sample covers all municipalities in the SR (2926) in the period $2005-2019$.

The paper is organized as follows: after the introduction, a literature review is presented. The second chapter provides the origin of data and gives the description of the methodology. The results are discussed in the third chapter followed by the conclusions and the list of references. 


\section{Literature Review}

Despite promotion of local governments and their financial autonomy by the European Charter of Local Self-Government (1985), the current empirical literature does not focus on measuring the financial autonomy of local governments directly. However, as mentioned by Beer-Tóth (2009) or Sellers and Lindström (2007), only minor attention is paid to local government financial autonomy in scientific literature, even though the field of the related empirical research is quite wide. Beside it, as mention Satoła, Standar and Kozera (2019, p. 322), the financial autonomy is a condition for the existence of self-government authorities.

According to Wolman et al. (2009), the term local autonomy is widely used among economists and non-professionals, but it is not conceptually defined. Oulasvirta and Turala (2009) mention that local government autonomy is basically composed of local decision-making power and financing, when local governments have to take care of tasks. As Adeyemo (2017) argues, the existence, power and autonomy of local government results from the law given by the superior government. Proper autonomy is determined by the nature and structure of relations between different (usually hierarchically configured) levels of the government. Ladner, Keuffer and Baldersheim (2016) follow the definition given in Lindström (1998) focusing on local autonomy conditions that cover circumscribed territory, authoritative power over the citizens and directly elected decision-makers. In literature, two terms connected to local autonomy could be found. Indeed, fiscal and financial autonomy are closely linked terms and in many empirical works the boundary between them is imperceptible. According to Gomes (2012), fiscal autonomy is a type of funding arrangement. The degree of fiscal autonomy is determined by the local (sub-national) governments' discretion over the allocation of funds and over the choice of public policies. Okafor (2010) defines financial autonomy of local governments as "freedom to impose local taxation, generate revenue within its assigned sources, allocate its financial and material sources, determine and authorize its annual budget without external interference" (Okafor, 2010, p. 126). In principle, the analyzed empirical research uses the same characteristics to measure the above-mentioned categories (e.g. Ladner, Keuffer and Baldersheim, 2016). Therefore, the paper employs the term financial autonomy to cover the research objective.

Undoubtedly, financial autonomy of local governments is connected to fiscal decentralization. In general, fiscal decentralization represents a process of shifting competences and responsibilities over provisioning of public goods from central government to local governments. According to early works by Musgrave (1959) and Oates (1972), independent decisions of local authorities in the area of expenditure must be accompanied by independent decision-making in the area of 
revenues. The increase of local independence in financing local tasks strengthens local financial autonomy taking into account political and socio-economic goals of the country (Musgrave, 1959). According to Oates (1999), Ebel and Yilmaz (2002), local governments should face the responsibility over their budget decisions and, simultaneously, they should have the possibility to affect their revenues, especially in the field of resource seeking (tax revenues). Similarly, Beer-Tóth (2009) mentions that local autonomy is not achieved until local governments have control over an adequate level of financial resources. In terms of the revenue autonomy component, she defines local financial autonomy as a right and an ability of local governments to determine the nature and the volume of financial resources, the rate at which beneficiaries shall contribute to the common pool and the way of their use.

However, the empirical research often analyses the local financial autonomy in relation to the degree of fiscal decentralization. It usually contains explanation and the description of basic pillars of successful fiscal decentralization mentioned by Ebel and Yilmaz (2002): revenue decentralization, expenditure decentralization, local borrowing and appropriate scheme of inter-governmental transfers. Blom-Hansen (1999) investigates intergovernmental relations with a focus on central-local policy in Scandinavian countries (Norway, Sweden and Denmark). Okafor (2010) investigates the impact of a particular financial instrument managed by central government on financial autonomy of local government in Nigeria. Local financial autonomy as a determinant of local indebtedness in Slovakia is used by Maličká (2017). Research directly focused on financial autonomy of local government is provided by e.g. Oulasvirta and Turala (2009). They investigate local financial autonomy in Finland and Poland. Ladner, Keuffer and Baldersheim (2016) measure local autonomy in 39 countries in the period $1990-2014$ observing its increase. In the field of taxation, they mention that local governments in Lichtenstein, Germany and Switzerland have the highest power to tax.

In the SR, local financial autonomy is evaluated by Nižňanský (2009), Klimovský (2013) and Maličká (2019). They mention the increase of financial autonomy of local governments after fiscal decentralization in 2005. Legal arrangements in the field of tax federalism were considered as appropriate. Local governments became free in raising local taxes (especially tax on immovable property) which, as a matter of fact, were really raised. Simultaneously, the economic expansion supported the increase of receipts from income taxes. As Nižňanský (2009) reminds or later Maličká mentions (2019), individual income tax as a shared tax in the SR divided on the basis of the population rather than on the basis of local tax power, creates a prevalent part of local revenues. Thus, a certain distorted perception of the real level of local financial autonomy is not excluded. However, 
local taxable resources are limited and often also depend on the socio-economic potential of localities, which is obviously different throughout the SR.

Discussing the existing inequalities among regions and municipalities in the SR, most authors point out two main problems: the fragmented residential structure and polarization of the economic activities. The fragmented residential structure is present over the whole territory of the country. Territorial localization of the economic activities causes regional disparities. The polarization of economic activities influences the distribution of population and distribution of taxable resources. Complex analysis of regional disparities in the SR is provided by Workie and Radvanský (2009). According to Klamár (2016), regional disparities measured in different ways increased during the period $2001-2014$ (covering the period of fiscal decentralization). OECD (2018) even mentions that the SR has the second highest regional disparities in the GDP per capita among the OECD members. Beside the frequent inter-regional analysis of the location of foreign direct investments, unemployment, population or socio-economic efficiency, Čapková (2009) contributes to empirical evidence by analyzing disparities in fiscal capacity of sub-national governments. She focuses on the new element in funding a regional government implemented by fiscal decentralization in the SR. As many authors before (and later), she reveals the leading position of the region adjacent to the capital city Bratislava. This confirms the expectation that disparities in financial autonomy exist, and it is possible that fiscal decentralization might work not only for their reduction, but also for their further deepening.

\section{Data and Methods}

To compute local financial autonomy, data are collected for each municipality in the SR on annual basis from the database provided by the Ministry of Finance of the SR. Data are available according to Act No. 211/2000 Coll. on free access to information. Data are collected taking into account the economic classification of revenues and expenditure, which is in details defined in Methodical Regulation of the Ministry of Finance of the SR No. MF/010175/2004-42 and explanatory notes on economic classification of the budget classification. It predetermines the panel data character of the dataset. The final panel covers 2926 crosssection units in period $2005-2019$. It means, that all the municipalities in the SR are included in the panel. In case of Bratislava and Košice, the city parts with own budgets and own elected incumbent are considered as separate units. Final panel is unbalanced due to records with missing data on key budget items (e.g. tax revenue). 
Demographical and geographical variables are derived from the DATACube database provided by the Statistical Office of the Slovak Republic (2021) and data about altitude and altitude coefficients are derived from the appendix of the Regulation of Government No. 668/2004 on territorial administration tax income division as amended by subsequent provisions. Problems are tied to data of cities with city parts, e. g. Košice and Bratislava have not data on area or population, because these data are encountered to the city parts, beside it, budget data are available. The choice of demographic and geographic indicators (see the bottom of the Table 1) is inspired by the paper on local financial autonomy published by Jemna, Onofrei and Cigu (2013). Their approach differs in the administrative size of the analyzed unit. While in this paper the financial autonomy of municipalities is examined, they rely on larger administrative units - counties. The indicators of the unemployment, area, population density or productive and unproductive population correspond to variables examined as local financial autonomy determinants in their research. Descriptive statistics of main budget, demographic and geographic variables is displayed in the Table 1 and Table 2.

Table 1

\section{Descriptive Statistics of Main Budget Variables}

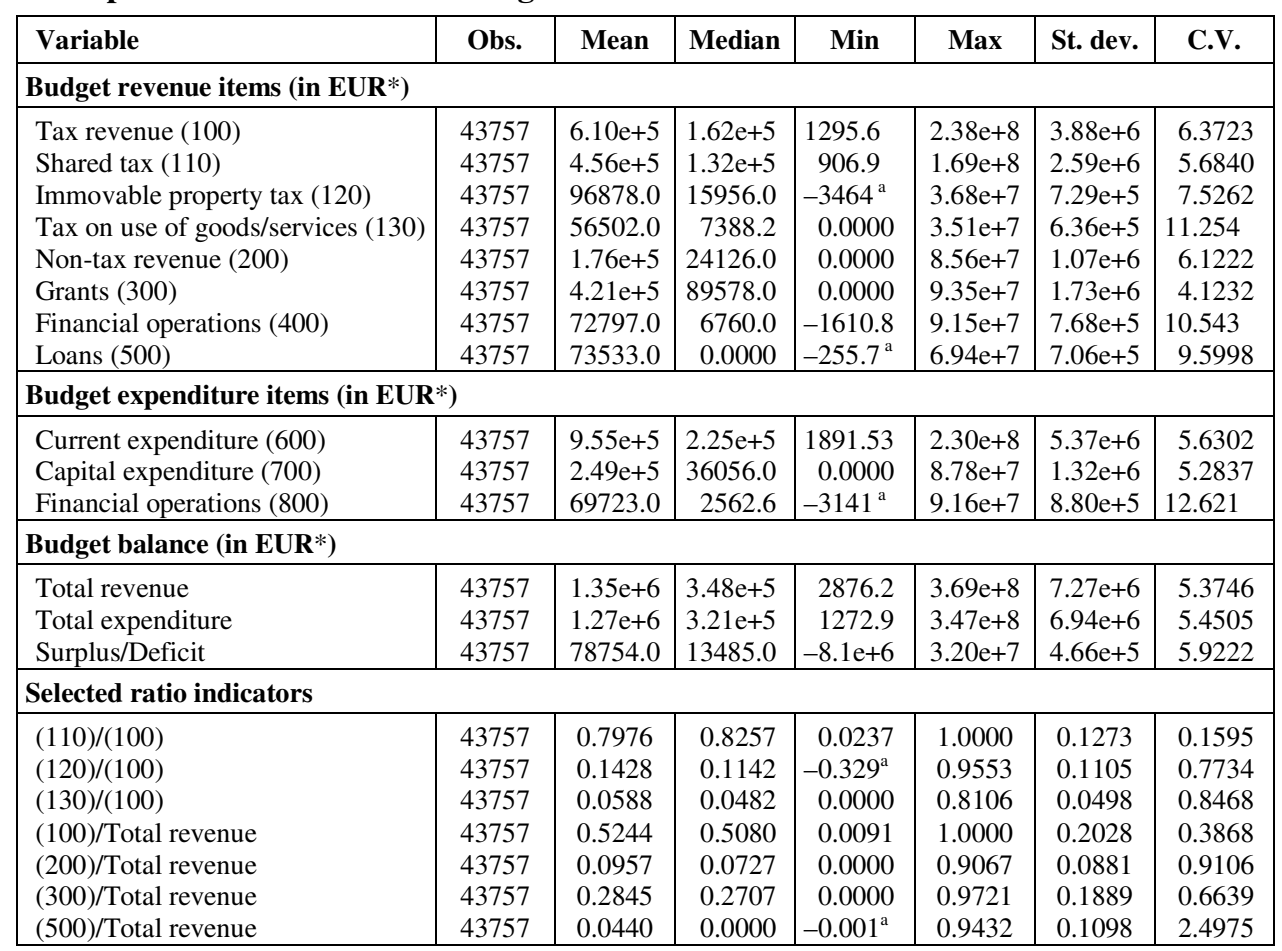

Note: ${ }^{a}$ negative value due to refunds. ${ }^{*}$ amounts in $2005-2008$ are converted to EUR by the exchange rate on December 31 of the correspondent year published by the ECB.

Source: Own processing. 
T a ble 2

Descriptive Statistics of Demographic and Geographic Variables

\begin{tabular}{|l|c|c|c|c|c|c|c|}
\hline Variable & Obs. & Mean & Median & Min & Max & St. dev. & C.V. \\
\hline Demography & 43890 & 2079.4 & 652.00 & 7.0000 & $4.38 \mathrm{e}+5$ & 10721 & 5.1559 \\
\hline Total population & 43875 & 320.84 & 104.00 & 0.0000 & 71931 & 1499.7 & 4.6743 \\
Population less 14 years & 43890 & 284.46 & 93.000 & 0.0000 & 81138 & 1583.6 & 5.5671 \\
Population over 65 years & 43890 & 162.81 & $0.0000^{*}$ & 0.0000 & 34867 & 802.95 & 3.4876 \\
Pupils (1 - 9 class primary school) & 43890 & 1474.2 & 449.00 & 2.0000 & $3.21 \mathrm{e}+5$ & 7695.0 & 5.2198 \\
Productive population (14 -65 years) & 43875 & 107.94 & 40.000 & 0.0000 & 13985 & 269.08 & 2.5677 \\
Number of unemployed persons & 43890 & 112.43 & 58.510 & 0.7500 & 14207 & 324.39 & 3.0053 \\
Population density & 43890 & 16.738 & 11.632 & 0.3579 & 380.06 & 18.742 & 1.1197 \\
\hline Geography & 43890 & 3.0988 & 3.0000 & 1.0000 & 10.000 & 1.5233 & 0.4916 \\
\hline Area in km ${ }^{2 * *}$ & 43890 & 307.83 & 252.50 & 97.000 & 1109.0 & 176.72 & 0.5741 \\
Size category*** & 43890 & 1.0104 & 0.9421 & 0.7500 & 2.0000 & 0.2183 & 0.2160 \\
Altitude in m & Coefficient of altitude
\end{tabular}

Note: * influenced by the absence of primary school in the municipality. ** Bratislava capital city and Košice city, the city area is divided among city parts, thus the Slovak Statistical Office displays 0. *** Size categories are scaled as 1 if population <199; 2 if $199<$ population <499; 3 if $>499<$ population < $999 ; 4$ if $999<$ population <1999; 5 if $1999<$ population <4999; 6 if $4999<$ population <9999; 7 if $9999<$ population $<19999 ; 8$ if $19999<$ population <49999; 9 if $49999<$ population <99999 and 10 if population $>99999$.

Source: Own processing.

Thus, to compute financial autonomy indicators, the budget data approach is used. The construction of indicators is inspired by the relevant literature e.g. Ribeiro and Jorge (2015), Scutariu and Scutariu (2015), Sharma (2012) or Fleurke and Willemse (2006). In the presented research, the following financial autonomy indicators are employed:

Indicator FAl - financial autonomy of local governments is expressed as a share of own local revenue on total local revenue. This indicator is supported by Ribeiro and Jorge (2015) or Scutariu and Scutariu (2015). Following the methodology of Sharma (2012), own revenue is computed as a sum of tax and non-tax revenues, thus receipts from the received grants and transfers are excluded. Tax revenues include the revenue from a shared tax (tax on income) and revenue from local taxes levied by the municipalities themselves (property taxes and taxes on goods and services, imposed tax penalties). Non-tax revenues include revenues from entrepreneurship and own property, administrative fees, fines and penalties, capital revenues, interests payments received and other non-tax revenues uncategorized above. The treatment of the indicator formality is active in terms of shared tax, which takes form of a "quasi grant" in the SR conditions (Maličká, 2019).

Indicator FA2 - financial autonomy of local governments is expressed as a share of local tax revenue on total local revenue, as also mentioned e.g. in Ribeiro and Jorge (2015). Here, the group of non-tax revenues is excluded from the analysis because of the low profitability. The treatment of the indicator formality is retained for the same reason as in the case of $F A l$ indicator. 
Indicator $F A 3$ - financial autonomy of local governments is expressed as a share of own local tax revenue on total local revenue. This indicator is derived from $F A 2$. It excludes the receipt from the shared tax to avoid weakness of the deductive approach indicators, which fail in the situation when capacity of municipalities to raise their own revenue is small (described e.g. by Fleurke and Willemse 2006).

Indicator FA4 - financial autonomy of local governments is expressed as a share of own local tax revenue and non-tax revenue on total local revenue. This indicator is derived from $F A 1$ and FA3 indicator. As mentions Sharma (2012), the non-tax revenue belongs to the revenue generated by the locality itself, and thus reflect on the effort and activity of the locality.

Descriptive statistics of financial autonomy variables is displayed in the Table 3.

Table 3

Descriptive Statistics of Financial Autonomy Variables

\begin{tabular}{|l|c|c|c|c|c|c|c|}
\hline Variable & Obs. & Mean & Median & Min & Max & St. dev. & C.V. \\
\hline \multicolumn{7}{|l|}{ Financial autonomy indicators } \\
\hline FA1 & 43757 & 0.6211 & 0.6200 & 0.0129 & 1.0000 & 0.2104 & 0.3387 \\
FA2 & 43757 & 0.5244 & 0.5080 & 0.0091 & 1.0000 & 0.2028 & 0.3868 \\
FA3 & 43757 & 0.1099 & 0.0841 & 0.0000 & 0.9463 & 0.0926 & 0.8427 \\
FA4 & 43757 & 0.2066 & 0.1792 & 0.0001 & 0.9730 & 0.1269 & 0.6139 \\
\hline
\end{tabular}

Note: * According to budget items listed in Table 1, FA1 $=((100)+(200)) /$ Total revenue FA2 $=(100) /$ Total revenue; FA3 $=((120)+(130)) /$ Total revenue; FA4 $=((120)+(130)+(200)) /$ Total revenue.

Source: Own processing.

However, in the literature on financial autonomy other indicators could be found. Ladner and Keuffer (2018) create an index to provide rankings, comparisons and further analyses. Meloche, Vaillancourt, and Yilmaz (2004) use measurements such as grants with autonomy, non-tax autonomy, tax autonomy, fiscal dependency and tax sharing (based on the data of OECD surveys) to characterize the revenue resources of the European post-communist countries. The contribution of Oulasvirta and Turala (2009) lies in evaluation of the local financial autonomy combining measurements of revenue and expenditure autonomy. Wolman et al. (2009) provide a Local Government Autonomy index constructed from several dimensions (e.g. local government importance, discretion, capacity, etc.). Ladner, Keuffer and Baldersheim (2016) used 11 different variables including the dummy variable expressing the possibility of local government to tax its population and a variable constructed as the proportion of local government revenues derived from their own resources (self-reliance).

In the paper, the inequalities across municipalities in the SR in terms of financial autonomy are examined using the Gini index for the monitored period 2005 2019. To elicit which factors determine the financial autonomy of municipalities 
in the SR, the regression analysis is run. The panel data approach employs the fixed-effect model (FEM) or the random effect model (REM). REM with SwamyArora/Baltagi and Chang transformation for unbalanced panels proposed by Baltagi and Chan (1994) are tested against the FEM using the Hausman test (null hypothesis: GLS estimates are consistent) (Hausman, 1978). To obtain robust results (robust standard errors), in FEM and REM, the estimates are adjusted by Arellano (2003) variance-covariance matrix, which allows a fully general structure - heteroscedasticity and serial (cross-sectional) correlation (Heteroskedasticity and autocorrelation consistent (HAC) covariance matrix). In addition, the other method is used simultaneously, when the estimates are adjusted by the BeckKatz standard errors (Panel Corrected Standard Errors, PCSE) (Beck and Katz, 1995). As discussed in Greene (2003), HAC is used in case of small T and large $\mathrm{n}$. In our sample, the $\mathrm{n}$ is large, and $\mathrm{T}$ is small when compared to $\mathrm{n}$, but not too small when compared to the empirical studies in this field. From this reason the Beck-Katz standard errors based on the feasible generalized least square estimator (FGLS) and proposed for large samples is used, too (Beck and Katz, 1995). To test the collinearity, the Belsely, Kuh and Welsh collinearity diagnostics is made (BKW diagnostics) (Belsley, Kuh and Welsh, 1980) as well as the Variance inflation factor (VIF) test of collinearity, which refers on value proposed by Neter, Wasserman and Kutner (1990). Panel models are estimated for each financial autonomy indicator separately.

\section{Results and Discussion}

The Figure 1 projects the financial autonomy indicators in the period 2005 2019 for the whole sample of municipalities in the SR. As expected, higher values are observed in the case of the $F A 1$ and $F A 2$ indicators in comparison with the rest of indicators, where the portion of the shared tax is excluded (FA3 and FA4). Concomitant effect of fixed criteria on the implementation of income tax sharing and parallel economic expansion is observed in the period $2005-2008$, when financial autonomy of municipalities in the SR measured as FA1 and FA2 increases. Contrary, measures based on own resources (FA3 and $F A 4$ ) decrease slightly in the same period, even if since the implementation of fiscal decentralization in 2005 up to now (2019), a lot of municipalities have raised the rate of immovable property tax to $280 \%$ compared to that in $2004(2004=100 \%$, according to Business Alliance of Slovakia, 2019). The portion of the shared tax shifted to the municipalities created the dominant part of municipal budgets and increased total revenue importantly. This causes, that the increase of the immovable property tax rates is not so evident. 
Fig u r e 1

Panel Plots of Financial Autonomy Indicators (group means)

FA1

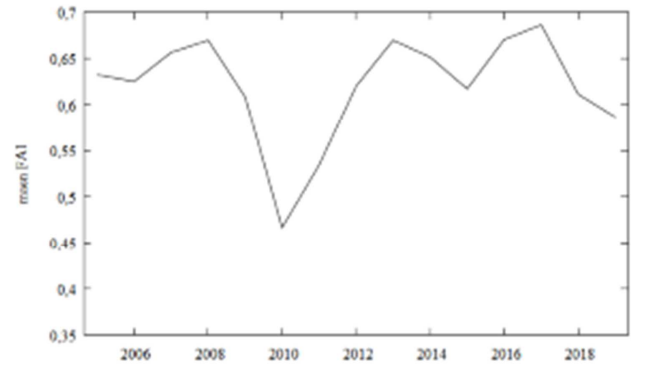

FA3

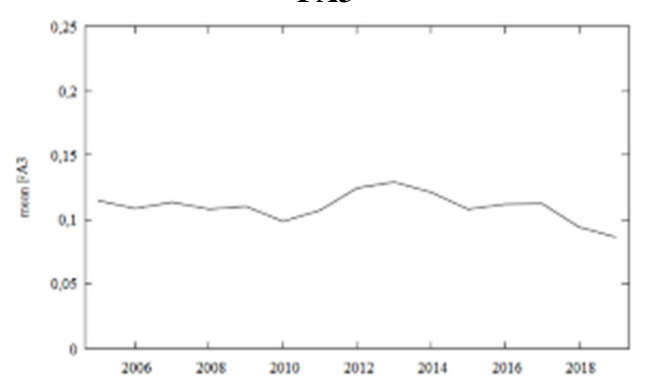

FA2

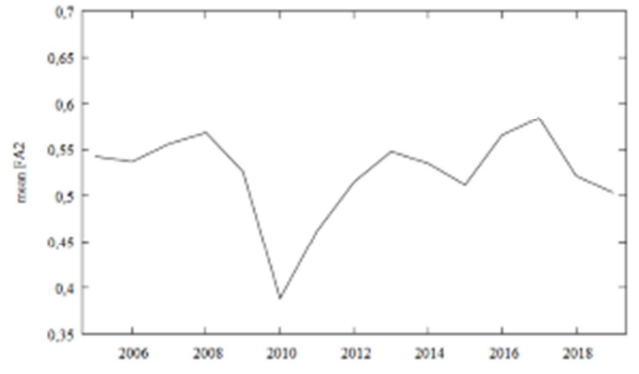

FA4

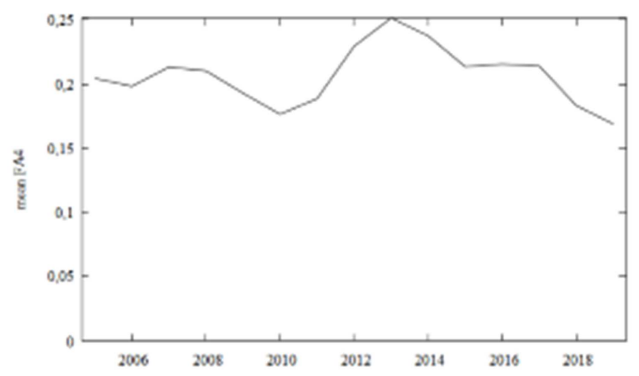

Source: Own processing.

Certain decrease of all monitored financial autonomy indicators is observed in the period of financial crisis (in 2009, with time delay due to the tax collection mechanism). Cuts in receipts from the personal income tax (shared tax) have influenced public budgets at all government levels. Through the shared tax channel, they influenced financial autonomy indicators $F A 1$ and $F A 2$ in the important manner. Beside it, the central government have legislatively reduced the portion of amount of shared tax dedicated to local self-governments in aim to create an additional source of revenue in the state budget to provide stabilization and redistribution centrally. The portion of sub-national governments (municipalities and regions) on shared tax decreased from $93.8 \%$ on $87.3 \%$ in 2012 in favor of the state budget and this situation continued also in 2013 (Maličká, 2017; 2019). After the economic recovery (in 2013 as mention Morvay et al., 2014) the central government has stepwise disorganized this fund totally (in comparison with the situation before the crisis) and resources from the shared tax were returned to local budgets. The portion of sub-national governments on shared tax increased to $88.9 \%$ in 2014 , in 2015 it increased to $95 \%$ and in 2016 it reached $100 \%$ (Maličká, 2017; 2019). Since 2016, the final portion of municipalities on the shared tax is $70 \%$. Before the financial crisis, this portion was legislatively 
arranged on $70.3 \%$. The portion of regions increased from $23.5 \%$ to current $30 \%$. An overview of fiscal decentralization in the SR is mentioned in (Maličká, 2019). Her research covers the period of the financial crisis, too.

Temporal decrease of local financial autonomy is observable in 2015, when total municipal revenue increased due to increase of received national capital grants and foreign grants. Quite surprising is a decrease of all financial autonomy indicators on the end of the monitored period, since 2017. In fact, since 2017 to 2018 , the growth of total municipal revenue reached $15 \%$, while the growth of tax revenue was $2 \%$ and of non- tax revenue was $10 \%$. In the group of tax revenues, the growth of the shared tax was $3 \%$, growth of the immovable property tax was $(-2) \%$ and the growth of other municipal taxes was $(-3) \%$. In the same period, the increase of the share of grants on total municipal revenue (from $23.3 \%$ to $28 \%$ ) is observable and its increase continued to $30 \%$ up to 2019.

Computing the Gini index of financial autonomy indicators, it is obvious, that the lowest inequalities are observed in the case of the FA1 and FA2 indicators (see Figure 2), where the portion of the shared tax is included. The obtained results mirror an effect of the system of horizontal equalization accentuating the construction of $F A 1$ and $F A 2$ indicator. As it is mentioned hereinbefore, it includes shared tax revenue, which is allocated to sub-national budgets through the fixed and complex system of indicators (since 2005). This system is tied to real demographic and geographic circumstances of sub-national units (regions and municipalities). They influence the particular economic profile and tasks of the sub-national unit. In the case of municipalities, apart from main criteria of population, it is e.g. a share of population aged over 62, altitude with the increasing coefficient for a higher altitude - due to higher costs of heating in public spaces such as schools etc., size of municipality - number of inhabitants with the increasing coefficient for a smaller municipality - due to the reduced tax base in small villages, number of pupils in primary schools. Hence, the original role of a shared tax is to create a suitable instrument to reduce horizontal inequalities in the tax base and make sub-national units able to provide necessary public services.

While in the case of $F A 1$ and $F A 2$ indicator, the role of shared tax in horizontal equalization is emphasized; in the case of $F A 3$ and $F A 4$ indicator this effect is excluded. While the strong impact of a shared tax spatially balances the local financial autonomy, the effect of employing the own resources is opposite. Hence, the exclusion of the element of horizontal equalization leads to different intensity of using FA3 and FA4 main components - the immovable property tax, taxes from use of goods and services and nontax revenues. Higher values of the Gini indices in the case of $F A 3$ and $F A 4$ point do higher inequalities among municipalities of the SR in terms of the ability to generate own resources. 
It is observable, that inequalities in the financial autonomy increased in the period of financial crisis, when the mean financial autonomy of all monitored indicators decreased. The sensitivity of financial autonomy of municipalities in the SR on worsened economic conditions is evident in the case of indicators, which include the shared tax. Between 2009 and 2010 the Gini index of the FAl increased by $43.8 \%$, the $F A 2$ by $36.6 \%$, while the $F A 3$ and $F A 4$ increased by $8.5 \%$ and $10.1 \%$. Certain short-term increase of inequalities is observable in 2015, when total municipal revenue increased due to increase of received national capital grants and foreign grants.

Figure 2

Gini Index of Financial Autonomy Indicators of Municipalities in the SR

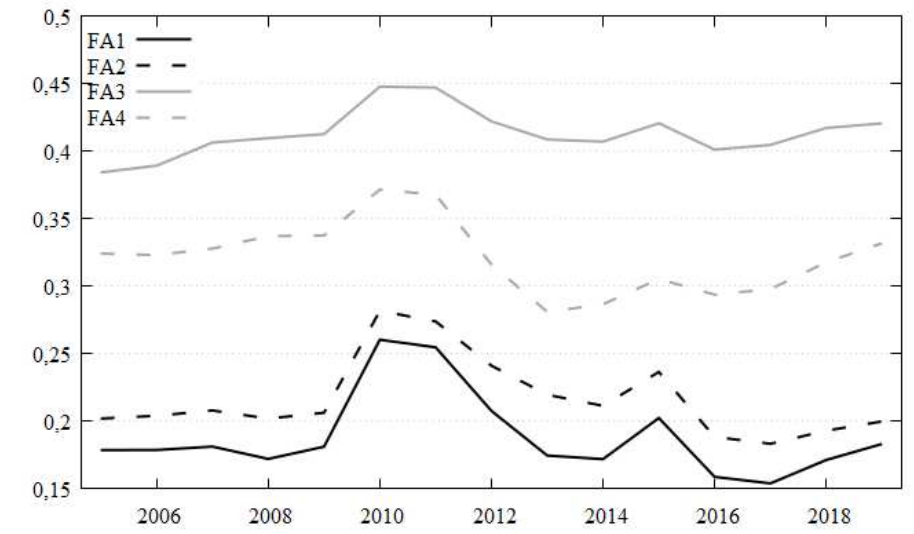

Source: Own processing.

However, the degree of financial autonomy indicators varies, the impact of demographic, geographic and budget variables on financial autonomy of municipalities in the SR is analyzed using the regression analysis. For each measure of financial autonomy (FA1, FA2, FA3 and FA4), separate models are estimated (see Table 4). First the REM model using the robust HAC is estimated and the consistency of GLS estimates is tested at the base of the Hausman test. After its results, eventually the alternative FEM model is estimated using the robust HAC. To provide the robustness check, the same procedure is repeated using the robust PCSE. The preliminary computation revealed a high correlation between the budget items listed in the Table 1 (e.g. tax revenue is correlated with current expenditure, because in the case of small municipalities, the revenue side of the budget is created predominantly by the tax revenue and all resources are spent on current tasks). It created certain limits on inclusion of mentioned variables to estimations in terms of collinearity. Final estimations show only statistically significant variables (see Table 4). 
T a b l e 4

Determinants of Financial Autonomy (various indicators) of Municipalities in the SR

\begin{tabular}{|c|c|c|c|c|c|c|c|c|}
\hline \multirow[t]{2}{*}{ Variables } & \multicolumn{2}{|c|}{ Model Fa1 } & \multicolumn{2}{|c|}{ Model Fa2 } & \multicolumn{2}{|c|}{ Model Fa3 } & \multicolumn{2}{|c|}{ Model Fa4 } \\
\hline & REM & REM & FEM & REM & FEM & REM & FEM & FEM \\
\hline & HAC & PCSE & HAC & PCSE & HAC & PCSE & HAC & PCSE \\
\hline Const & $\begin{array}{c}0.664 \\
* * * \\
(0.003) \\
\end{array}$ & $\begin{array}{c}0.664 \\
* * * \\
(0.028) \\
\end{array}$ & $\begin{array}{c}0.572 \\
* * * \\
(0.020) \\
\end{array}$ & $\begin{array}{c}0.560 \\
* * * \\
(0.024) \\
\end{array}$ & $\begin{array}{c}0.568 \\
* * * \\
(0.011)\end{array}$ & $\begin{array}{c}0.589 \\
* * * \\
(0.017)\end{array}$ & $\begin{array}{c}0.646 \\
* * * \\
(0.013)\end{array}$ & $\begin{array}{c}0.646 \\
* * * \\
(0.003)\end{array}$ \\
\hline Population & $\begin{array}{l}-0.129 \\
* * * \\
(0.034)\end{array}$ & $\begin{array}{c}-0.121 \\
* * * \\
(0.045)\end{array}$ & $\begin{array}{c}-0.110 \\
* * * \\
(0.032)\end{array}$ & $\begin{array}{c}-0.130 \\
* * * \\
(0.042)\end{array}$ & $\begin{array}{c}-0.030 \\
* * \\
(0.012)\end{array}$ & $\begin{array}{c}-0.037 \\
* * \\
(0.016)\end{array}$ & $\begin{array}{c}-0.041 \\
* * \\
(0.019)\end{array}$ & $\begin{array}{c}-0.041 \\
* \\
(0.024)\end{array}$ \\
\hline $\begin{array}{l}\text { Shared tax to } \\
\text { tax revenue } \mathrm{e}^{\mathrm{a}}\end{array}$ & & & & & $\begin{array}{c}-0.564 \\
* * * \\
(0.013) \\
\end{array}$ & $\begin{array}{l}-0.590 \\
* * * \\
(0.019)\end{array}$ & $\begin{array}{c}-0.533 \\
* * * \\
(0.016) \\
\end{array}$ & $\begin{array}{c}-0.533 \\
* * * \\
(0.038) \\
\end{array}$ \\
\hline $\begin{array}{l}\text { Loans } \\
\text { to total } \\
\text { revenue }^{\mathrm{b}}\end{array}$ & $\begin{array}{c}-0.818 \\
* * * \\
(0.007)\end{array}$ & $\begin{array}{c}-0.818 \\
* * * \\
(0.036)\end{array}$ & $\begin{array}{c}-0.694 \\
* * * \\
(0.007)\end{array}$ & $\begin{array}{c}-0.696 \\
* * * \\
(0.034)\end{array}$ & $\begin{array}{c}-0.155 \\
* * * \\
(0.003)\end{array}$ & $\begin{array}{c}-0.157 \\
* * * \\
(0.007)\end{array}$ & $\begin{array}{c}-0.279 \\
* \\
(0.005)\end{array}$ & $\begin{array}{c}-0.279 \\
* * * \\
(0.011)\end{array}$ \\
\hline $\begin{array}{l}\text { Structural } \\
\text { break (2009) }\end{array}$ & $\begin{array}{c}-0.080 \\
* * * \\
(0.003) \\
\end{array}$ & $\begin{array}{c}-0.080 \\
* * * \\
(0.029) \\
\end{array}$ & $\begin{array}{c}-0.073 \\
* * * \\
(0.003) \\
\end{array}$ & $\begin{array}{c}-0.072 \\
* * * \\
(0.022) \\
\end{array}$ & $\begin{array}{c}-0.019 \\
* * * \\
(0.001) \\
\end{array}$ & $\begin{array}{c}-0.020 \\
* * * \\
(0.004) \\
\end{array}$ & $\begin{array}{c}-0.025 \\
* * * \\
(0.002) \\
\end{array}$ & $\begin{array}{c}-0.025 \\
* \\
(0.015) \\
\end{array}$ \\
\hline R2 & 0.325 & 0.325 & 0.291 & 0.291 & 0.409 & 0.409 & 0.231 & 0.231 \\
\hline $\begin{array}{l}\text { Hausman test } \\
\text { p-value }\end{array}$ & 0.212 & 0.817 & $<0.001$ & 0.282 & $<0.001$ & 0.112 & $<0.001$ & $<0.001$ \\
\hline $\begin{array}{l}\text { BKW } \\
\text { Diagnostics }\end{array}$ & $>=10: 0$ & $>=10: 0$ & $>=10: 3$ & $>=10: 0$ & $>=10: 4$ & $>=10: 1$ & $>=10: 1$ & $>=10: 1$ \\
\hline VIF test & $<10$ & $<10$ & $<10$ & $<10$ & $<10$ & $<10$ & $<10$ & $<10$ \\
\hline No of obs. & 40839 & 40839 & 40839 & 40839 & 40839 & 40839 & 40839 & 40839 \\
\hline $\begin{array}{l}\text { No of cross - } \\
\text { sectional } \\
\text { units }\end{array}$ & 2926 & 2926 & 2926 & 2926 & 2926 & 2926 & 2926 & 2926 \\
\hline
\end{tabular}

Notes: ${ }^{\mathrm{a}}$ variable is listed in Table 1 as $(110) /(100) .{ }^{\mathrm{b}}$ variable is listed in Table 1 as $(500) /$ Total revenues. $(* * *)$ $=0.01,(* *)=0.05,(*)=0.1$ denotes significance levels; standard errors in parentheses; FEM - Fixed effect model, REM - Random effect model, (Swamy-Arora/Baltagi Chan transformation); HAC or PCSE - Arellano (2003) or Beck and Katz (1995) robust standard errors employed.

Source: Own processing.

The population variable is one of the basic measures of the size of the municipality. It is expectable, that the fiscal need of the municipality depends on the municipality size. To deal with the horizontal inequalities, the intergovernmental grant system is often attached to the municipality size. The structure of the population also plays an important role in the shift of resources from the central to lower government level. The high portion of the unproductive population creates the pressure on public budgets. Beside it, it points to the economic circumstances of the municipality and, as mention Jemna, Onofrei and Cigu (2013), it contributes to the lower level of financial autonomy of the municipality. The estimation results show the negative impact of the population on the financial autonomy indicators. In the monitored period 2005 - 2019 the mean population growth (measured in log differences) in the sample is rather stable. More evident is an 
increase of the population in the period before beginning the financial crisis 2007 up to 2011. This increase is linked to a higher fertility, as is stated in Podmanická (2017). In the same time, all indicators of the financial autonomy of municipalities in the SR have decreased. These antagonistic movements caused the observed negative relationship.

In fact, the financial autonomy of municipalities in the SR is low, when taking into account own tax and nontax revenue (indicators $F A 3$ and $F A 4$, see Figure 1). As Satoła, Standar, and Kozera (2019) stress, the problem of small municipalities is, that they have only limited capacity to deal with their own tasks and thus they strongly depend on allocations from the central budget. From this reason the indicator of the ratio of shared tax on tax revenue was included to the estimation.

The estimation results show, that the effect of the portion of the shared tax on municipal tax revenues is statistically significant and negative in the case of the FA3 and FA4 indicator. Generally, the portion of the shared tax on tax revenue is dominant in the local tax mix and presents in average $80 \%$ of municipal tax revenue in the monitored period, reaching its minimum in 2010 (75.92\%). It means, that the portion of local taxes is low and presents about one fifth of municipal tax revenue, what was earlier observed also in Horváthová (2009) at the base of the questionnaire survey. Thus, the financial autonomy based on the own revenue (own tax and nontax revenue) is constrained by the equalization quasi transfer provided in the form of shared tax (Maličká, 2019). Additionally, as states Propheter (2019), the reliance of municipalities on receipts from central government budget (shared tax) and the soft budget constraint decline the motivation of subnational governments to generate own resources.

As it is obvious from the Figure 1, all financial autonomy indicators have recorded an evident decrease in the period of financial crisis (since 2009). The preliminary investigation showed, that in the same time the share of returnable financial resources (loans) on total revenue increased by $10 \%$. It raised total municipal revenue with the concomitant decrease of tax and nontax revenue items. The relationship between all the financial autonomy indicators and the share of returnable resources on total municipal revenue is negative. Similar relation was observed in Maličká (2017).

However, the financial autonomy on municipalities in the SR is determined by several factors. Beside it, the sensitivity of the financial autonomy of municipalities in the SR on external shocks is evident (see Figure 1 and Figure 2). The structural break in the form of the financial crisis influenced the central government budget, as well as local budgets. Estimation results show the negative relationship between all the financial autonomy indicators and the financial crisis time dummy variable. It signalizes, that in the period of financial crisis the financial autonomy of municipalities in the SR decreases. 


\section{Conclusion}

In the research focused on local governments, the field of financial autonomy is frequently discussed when measuring overall local autonomy. The increase of financial autonomy of local governments in the SR is mentioned by several authors. In general, it is closely linked to fiscal decentralization in 2005. At that time, legal arrangements in the field of tax federalism were made to strengthen the role of local governments in provisioning local public goods. As it is mentioned by several sources related to research of disparities and inequalities in the $\mathrm{SR}$, the distribution of taxable resources across the country is not uniform. Local taxable resources are limited and often also depend on the socio-economic potential of the localities, which obviously differs across the SR. Despite the legal framework adopted in 2005 aimed at implementing certain elements of solidarity (e.g. criteria for division of shared tax), horizontal inequalities persist. The observed increase of financial autonomy of local governments raised the question whether there was any real prospect of equalization of local financial autonomy.

In this paper, the financial autonomy of municipalities in the SR is investigated. The research sample covers all municipalities in the SR (2926) in period 2005 2019. To express local financial autonomy, revenue based indicators are employed. Following the budget data approach, four types of financial autonomy are computed. Two financial autonomy indicators are covering the portion of the shared tax shifted to local budgets from the central government budget. The rest two financial autonomy indicators rely on own resources, which contain own tax revenue and nontax revenue. As expected, the financial autonomy measured by indicators including the shared tax is much higher than financial autonomy measured by indicators based on own resources. The results of the analysis of inequalities among municipalities in the SR in terms of local financial autonomy show, that the shared tax has a potential to deal with horizontal fiscal inequalities. Higher inequalities measured using the Gini index are observed in the case of the exclusion of shared tax from indicators.

The local financial autonomy in the SR is influenced by the demographic variables and budget variables and financial crisis affecting local governments in the SR with a certain delay in 2009. Employing the panel regression, the negative relationship is observed in the case of population growth, use of returnable financial resources and in the time of financial crisis and also portion of shared tax on municipal tax revenue, when considering the financial autonomy based on own municipal resources.

Anyway, the current (and expected) undesired demographic evolution and dynamic development of metropolitan areas in the SR leave the investigated question open. Dying out of small settlements (deepening of the problem of 
fragmented residential structure and insufficient tax base of municipalities with a low number of inhabitants), the overall anticipated decrease of fertility and ageing of the population will bring different results in similar research in the future. Beside it, the research confirms the reliance of municipalities in the SR on economic development and external shocks. The effects of contemporaneous crisis with non-economic origin on public finance are evident even now and without any doubt they will mirror in the degree of financial autonomy of municipalities in the SR. As time will go on, these effects would be analyzed, too.

\section{References}

ADEYEMO, D. O. (2017): Local Government Autonomy in Nigeria: A Historical Perspective. Journal of Social Sciences, 10, No. 2, pp. 77 - 87. Available at: <https://doi.org/10.1080/09718923.2005.11892462>.

ARELLANO, M. (2003): Panel Data Econometrics. Oxford: Oxford University Press.

BALTAGI, B. H. - CHANG, Y.-J. (1994): Incomplete Panels: A Comparative Study of Alternative Estimators for the Unbalanced One-way Error Component Regression Model. Journal of Econometrics, 62, No. 2, pp. $67-89$.

BECK, N. - KATZ, J. (1995): What to Do (and Not to Do) with Time-Series Cross-section Data. American Political Science Review, 89, No. 3, pp. 634 - 647. Available at: <https://doi:10.2307/2082979>.

BEER-TÓTH, K. (2009): Local Financial Autonomy in Theory and Practice. The Impact of Fiscal Decentralisation in Hungary. [PhD Dissertation.] Fribourg: University of Fribourg Switzerland.

BELSLEY, D. A. - KUH, E. - WELSCH, R. E. (1980): Regression Diagnostics: Identifying Influential Observations and Sources of Collinearity. New York: John Wiley \& Sons.

BLAIR, P. (1991): Trends in Local Autonomy and Democracy: Reflections from a European Perspective. In: BATLEY, R. and STOKER, G. (eds): Local Government in Europe. Government beyond the Centre. London: Palgrave, pp. $41-57$.

BLOM-HANSEN, J. (1999): Policy-Making in Central-local Government Relations: Balancing Local Autonomy, Macroeconomic Control, and Sectoral Policy Goals. Journal of Public Policy, 19, No. 3, pp. 237 - 264. Available at: <https://doi.org/10.1017/S0143814X99000690>.

BUSINESS ALLIANCE OF SLOVAKIA (2019): Mestá nevyužívajú potenciál daní z nehnutel'ností ani poplatku za rozvoj. Bratislava: Business Alliance of Slovakia. Available at: $<$ https://www.alianciapas.sk>.

ČAPKOVÁ, S. (2009): Disparity vo výnosoch miestnych daní regionálnych samospráv na Slovensku. In: WORKIE, T. M. and RADVANSKÝ, M. (eds): Trendy regionálnych disparít Slovenska: teoretické modely a empirické analýzy. Bratislava: Ekonomický ústav SAV, pp. 169 - 182.

EBEL, R. D. - YILMAZ, S. (2002): Concept of Fiscal Decentralization at Worldwide Overview. Washington, DC: World Bank. Available at: <http://documents.worldbank.org/curated/en/716861468781761314/Concept-of-fiscaldecentralization-and-worldwide-overview $>$.

EUROPEAN COMMISSION (1985): European Charter of Local Self-government. Luxembourg: European Commission.

EUROPEAN COMMISSION (undated): Eurostat. Luxembourg: European Commission. Available at: <https://ec.europa.eu/eurostat>.

FLEURKE, F. - WILLEMSE, R. (2006): Measuring Local Autonomy: A Decision-making Approach. Local Government Studies, 32, No. 1, pp. 71 - 87. Available at: <https://doi.org/10.1080/03003930500453542>. 
GOMES, S. (2012): Fiscal Powers to Subnational Governments: Reassessing the Concept of Fiscal Autonomy. Regional \& Federal Studies, 22, No. 4, pp. 387 - 406. Available at: <https://doi.org/10.1080/13597566.2012.679849>.

GREENE, W. H. (2003): Econometric Analysis. Fifth ed. Upper Saddle River, NJ: Prentice-Hall.

HAUSMAN, J. A. (1978): Specification Tests in Econometrics. Econometrica 46, No. 6, pp. 1251 - 1271. Available at: 〈https://doi.org/10.2307/1913827>.

HORVÁTHOVÁ, L. (2009): Pravidlá decentralizácie treba upravit': námety pre komunálnu reformu, ktoré vyplynuli z reprezentatívneho výskumu. Verejná správa, 64, No. 23, pp. $22-23$.

JEMNA, D. - ONOFREI, M. - CIGU, E. (2013): Demographic and Socio-Economic Determinants of Local Financial Autonomy in Romania. Transylvanian Review of Administrative Sciences, 9, No. 39, pp. $46-65$.

KLAMÁR, R. (2016): Development Tendencies of Regional Disparities in the Slovak Republic. Geographica Pannonica, 20, No. 3, pp. 136 - 151. Available at: <https://doi.org/10.5937/GeoPan1603136K>.

KLIMOVSKÝ, D. (2013): Územná samospráva na Slovensku. Rozvoj sídelných štruktúr od roku 1939 do súčasnosti (2). Obec a finance, 18, No. 3, pp. $74-77$.

LADNER, A. - KEUFFER, N. (2018): Creating an Index of Local Autonomy - Theoretical, Conceptual, and Empirical Issues. Regional \& Federal Studies, 31, No. 2, pp. 209 - 234. Available at: 〈https://doi.org/10.1080/13597566.2018.1464443>.

LADNER, A. - KEUFFER, N. - BALDERSHEIM, H. (2016): Measuring Local Autonomy in 39 Countries $(1990$ - 2014). Regional \& Federal Studies, 26, No. 3, pp. 321 - 357. Available at: <https://doi.org/10.1080/13597566.2016.1214911>.

LINDSTRÖM, A. (1998): The Comparative Study of Local Government Systems: A Research Agenda. Journal of Comparative Policy Analysis: Research and Practice, 1, No. 1, pp. 97 - 115. Available at: 〈https://doi.org/10.1080/13876989808412617>.

MALIČKÁ, L. (2017): Determinants of Local Indebtedness in the Slovak Republic. Politická ekonomie, 65, No. 3, pp. 301 - 315. Available at: 〈https://doi.org/10.18267/j.polek.1145>.

MALIČKÁ, L. (2019): Formal Dimension of Fiscal Decentralization in Context of the Vertical Fiscal Imbalance and Financial Autonomy of Municipalities in the SR. Politická ekonomie, 67, No. 3, pp. 273 - 290. Available at: 〈https://doi.org/10.18267/j.polek.1240>.

MORVAY, K. et al. (2014): Hospodársky vývoj Slovenska v roku 2013 a výhl’ad do roku 2015. Bratislava: Ekonomický ústav SAV. ISBN 978-80-7144-224-0.

MELOCHE, J. PH. - VAILLANCOURT, F. - YILMAZ, S. (2004): Decentralization or Fiscal Autonomy? What Does Really Matter? Effects on Growth and Public Sector Size in European Transition Countries. [Policy Research Working Paper, No. WPS 3254.] Washington, DC: World Bank. Available at:

<http://documents.worldbank.org/curated/en/884061468770987596/Decentralization-or-fiscalautonomy-What-does-really-matter-effects-on-growth-and-public-sector-size-in-Europeantransition-countries>.

MUSGRAVE, R. (1959): The Theory of Public Finance: A Study in Public Economy. New York: McGraw-Hill.

NETER, J. - WASSERMAN, W. - KUTNER, M. H. (1990): Applied Linear Statistical Models. Boston: Irwin.

NIŽŇANSKÝ, V. (2009): Posilnenie finančnej autonómie miest a obcí: Analýzy-argumenty-názory, pracovné materiály. Bratislava: M.E.S.A.

NIŽŇANSKÝ, V. - CIBÁKOVÁ, V. - HAMALOVÁ, M. (2014): Tretia etapa decentralizácie verejnej správy na Slovensku. Bratislava: Wolters Kluwer.

OATES, W. E. (1972): Fiscal Federalism. New York: Harcourt Brace Jovanovich.

OATES, W. E. (1999): An Essay on Fiscal Federalism. Journal of Economic Literature, 37, No. 3, pp. 1120 - 1149. Available at: 〈http://dx.doi.org/10.1257/jel.37.3.1120〉.

OECD (2018): Regions and Cities at a Glance 2018 - Slovak Republic. Paris: OECD. Available at: $<$ http://www.oecd.org/regional/>. 
OKAFOR, J. (2010): Local Government Financial Autonomy in Nigeria: The State Joint Local Government Account. Commonwealth Journal of Local Governance, No. 6, pp. $124-131$. Available at: <https://doi.org/10.5130/cjlg.v0i6.1621>.

OULASVIRTA, L. - TURALA, M. (2009): Financial Autonomy and Consistency of Central Government Policy towards Local Governments. International Review of Administrative Sciences, 75, No. 2, pp. 311 - 332. Available at: <https://doi.org/10.1177/0020852309104178>.

PODMANICKÁ, Z. (ed.) (2017): Štatistika v súvislostiach: Hlavné trendy populačného vývoja v SR v roku 2016. Bratislava: Štatistický úrad Slovenskej republiky. ISBN 978-80-8121-610-7.

PROPHETER, G. (2019): An Exploration of Revenue Structure Characteristics in Rural Municipalities. State and Local Government Review, 51, No. 1, pp. 46 - 56.

RIBEIRO, N. A. B. - JORGE, S. M. F. (2015): Political-Ideological Circumstances and Local Authorities' Debt: Evidence from Portuguese Municipalities. Contemporary Economics, 9, No. 2, pp. 155 - 170. Available at: 〈https://doi.org/10.5709/ce.1897-9254.164〉.

SATOŁA, Ł. - STANDAR, A. - KOZERA, A. (2019): Financial Autonomy of Local Government Units: Evidence from Polish Rural Municipalities. Lex Localis, 17, No. 2, pp. $321-342$. Available at: 〈http://dx.doi.org/10.4335/17.2.321-342(2019)>.

SCUTARIU, A. L. - SCUTARIU, P. (2015): The Link between Financial Autonomy and Local Development. The Case of Romania. Procedia Economics and Finance, 32, pp. 542 - 554. Available at: <https://doi.org/10.1016/S2212-5671(15)01430-6>.

SELLERS, J. M. - LINDSTRÖM, A. (2007): Decentralization, Local Government and the Welfare State. Governance - An International Journal of Policy, Administration, and Institutions, 20, No. 4, pp. 609 - 632. Available at: 〈https://doi.org/10.1111/j.1468-0491.2007.00374.x〉.

SHARMA, CH. K. (2012): Beyond Gaps and Imbalances: Restructuring the Debate on Intergovernmental Fiscal Relation. Public Administration - an International Quarterly, 90, No. 1, pp. 99 - 128. Available at: 〈https://doi.org/10.1111/j.1467-9299.2011.01947.x〉.

STATISTICAL OFFICE OF THE SLOVAK REPUBLIC (2021): DATACube. Bratislava: Statistical Office of the Slovak Republic. Available at: 〈http://datacube.statistics.sk/>.

WOLMAN, H. - McMANNON, R. - BELL, M. - BRUNORI, D. (2008): Comparing Local Government Autonomy across States. [GWIPP Working Paper.] Washington, DC: George Washington Institute of Public Policy.

WORKIE, T. M. - RADVANSKY, M. (2009): Trendy regionálnych disparít Slovenska: teoretické modely a empirické analýzy. Bratislava: Ekonomický ústav SAV. 